\title{
THE GERMAN CONTRIBUTION TO THE MILITARY HISTORY OF SOUTH AFRICA AND SOUTH-WEST AFRICA
}

\author{
INTRODUCTION
}

The Republic of South Africa is the spiritual, cultural, cconomic and military extension of the Occident on the Southern extremity of Africa.

Situated where it is, it does not only form an invaluable link between the East and the West, but at the same time it is one of the most important approaches to the Southern part of the African continent.

The foundation of the white society at the Cape was laid by representatives from various Western European nations. In the course of time each one of them contributed towards the development of a young, vigorous nation in this vasi land under the Southern Cross - a nation which, since its birth, has always recognised the guidance of the Almighty God.

During this process of growih, various elemenis have merged into a nation in a new homeland: the fatherland of the South Africans.

A variety of influences, among which the German can be regarded as one of the most imporiant, played a significant role in the development of a new nation with its own character.

The present South African nation has not forgotten the manifold sacrifices of these founders and builders.

Among the oldest ancestors of our nation there are some prominent Germans. From the latest scientific findings, as obtained by Dr. J. A. Heese, it appears among others that during the period 1652-1807 the white population of the Cape Colony consisted of $38 \%$ persons of Dutch, $35 \frac{1}{2} \%$ of German and $14 \%$ of French origin, whercas Swcides, Danes and other nationalities comprised 3\% of the total population and $9 \frac{1}{2} \%$ must be regarded as unascertainable.

This strong German element in the oldest white population nucleus can be traced, among other things, in the great number of German surnames that appear in the various genealogical works. Of the surnames, which have come to us in their Afrikaans or original form, the following - chosen at random - are striking examples : Badenhorst, Biermann, Botha, Breytenbach, Combrink, Dreyer, Eloff, Fischer, Gericke, Hertzog, Hofmeyr, Immelmann, Kruger, Lessing, Maritz, Olckers, Preller, Rautenbach, Sauer, Truter, Ungerer, Wagner and Zinn.

And after this period a great many Germans went on to settle in our country and became part and parcel of our nation.

Of more recent times there is the group who may indeed still feel the spiritual ties with the country of origin, but who have in all other respects become full-fledged countrymen and members of our nation. 
Finally there are those German immigrants who must be regarded as the guests of our nation. It is they who are trying to strike out in a new, and at the beginning partially strange environment, they who are at the various stages of adjusting themselves to and identifying themselves with our country and nation.

In the course of time this group, just like their predecessors from the same country will also be able to state with pride: Thy people shall be my people.

Representatives from the latter group will draw more than ample inspiration from the significant contributions of their former countrymen to the development of our country and nation so that, in course of time, they may also answer to the call of South Africa!

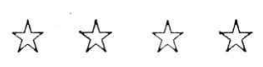

This brief review was given with a threefold purpose.

First of all it represents an effort to outline the German contribution to the military history of our country and South-West Africa.

Secondly we aim to brief the German immigrants with regard to one of the many fields in which some of their predecessors worked so diligently and thus undoubtedly contributed towards the birth and growth of our own military tradition.

Finally this publication is one of the numerous means to bring closer together those who take a natural interest in one another's past, present and future.

Thus existing ties will be strengthened. topic :

The compilers concentrated on the following aspects of their stated

1. German military contributions during the period of Dutch management.

2. The German Legion.

3. Maj. R. F. W. Albrecht.

4. The South African Republic.

5. Germans during the Anglo Boer War.

6. South-West Africa.

Of course, there is much more data and readers who are interested, are thus guided further along the military road of South Africa and South-West Africa by a short bibliography. This road is centuries old, a road which after more than three centuries led to the long cherished political freedom and independence.

True to the military traditions of a proud ancestry, every able-bodied South African is ready at all times to render the supreme sacrifice in defence of his hard-won freedom and independence.

In the hour of danger, in the hour when he has to defend his existence as a free nation, the South African, together with his fellow countrymen, joins the ranks around the colours on which is written in golden letters :

Our Country, our People, our Fatherland South Africa.

And by this symbol, supported and strengthened by the Lord of Hosts, he will conquer! 


\section{THE BEGINNING}

In 1652 the Dutch East India Company founded an important military and maritime post at the Cape of Good Hope, thus not only paving the way for white colonisation on the Southern tip of Africa, but also, as would turn out later, sowed the first seeds for what was ultimately to become the South African nation.

In the course of the 17 th and 18 th centuries this mighty Dutch trading company employed thousands of representatives from various Western countries, among which Germany and the German Dutch border area. Not only did they look after the trading interests of the company in the wide-spread settlements with pen and sword, but they very often settled permanently as free burghers in the colony after leaving the services of the company.

They, the Free Burghers, laid the foundation of the future South African nation, whereas the company officials stayed at the Cape for longer and shorter periods and only very few of them settled permanently in the country.

\section{WIDE-SPREAD INFLUENCE}

Although exclusive stress is laid on German military influence on the history of South Africa in this short review, it must be born in mind that, both during and after the reign of the company, traces of German influence are evident in almost all spheres of life in our country.

The following examples will serve to stress the point :

The physician Heinrich Claudius hailing from Breslau collected a herbarium during his stay at the Cape, accompanied the well-known Olof Bergh on his overland tour in 1683 and kept the journal, and was also a member of Governor Simon van der Stel's expedition in 1685.

Henning Hüsing (Huising) who started his career in our country as a soldier, and, as rich land owner and influential colonist, played an important part in opposing Governor Willem Adriaan van der Stel at the beginning of the 18th century.

Joachim Nicolaus von Dessin, from Rostock, who arrived as a soldier at the Cape in 1727, acted among other things, as bookkeeper and secretary of the Cape Orphan Chamber and left his invaluable library to the local parish.

Anton Anreith who, in 1777, arrived as a soldier at the Cape aboard the Woestduyn and made a name for himself as sculptor and artist. Dr. Friedrich Ludwig Liesching laid ou: a botanical garden in the vicinity of Cape Town just after 1800. His contemporary, Herman Schutte, from Bremen, was responsible, among other things, for the design and construction of the well-known Groote Kerk in Cape Town.

Missionary Georg Schmidt founded the Baviaanskloof missionary station, the Rev. Meent Borcherds preached the Gospel at Stellenbosch from 1786 to 1830, whereas Johann Christiaan Ritter printed the first Cape almanac on his Cape Town press.

Finally, with reference to this period, Martin Melck may be mentioned as the proud owner of Elsenburg and architect of the well-known Lutheran Chapel and the still existing sexton's residence in the heart of Cape Town. 
These are but a few examples of the meritorious work done by Germans in the south during the 17 th and 18 th centuries. With them we also give credit to those of German descent who, each in his own modest sphere, contributed towards a characteristic South African military tradition.

\section{GERMAN MILITARY CONTRIBUTIONS DURING THE PERIOD OF DUTCH MANAGEMENT}

The military history of our country begins when, in 1651, the Lords Seventeen commissioned Jan van Riebeeck to build a fort at the foot of Table Mountain.

In a strategic sense the Cape was not merely the key to the Netherlands colonial empire in the Orient, but at the same time also the entrance to that Empire, where possible competitors could be brought to a halt.

Shortly after van Riebeeck's landing at Table Bay, the first war between the Netherlands and England broke out over the control of trade and shipping on the oceans. In 1665 the second naval war broke out and between 1672 and 1674 the two competitors once more came to grips.

During the 17th and 18th centuries, the fortification of the Cape was an urgent necessity. While van Riebeeck was commander at the Cape, the first fort, De Goede Hoop, a number of field defensive works and guard posts were erected. His successor, the German-born commander Zacharias Wagenaer (Wagner), laid one of the foundation stones of the present Castle in 1666.

Up to the end of Dutch period in our country's history the Castle would remain the centre of a military post from which gradually sprang Cape Town and the Cape Colony. It was a military, civil and social centre of an unfolding nation.

The German regular and ex-servicemen played a part in the defence of the two successive forts De Goede Hoop as well as in the organisation and command of the professional garrisons and the Citizen Force in the Cape Colony. Some of them were also members of expeditions into the interior and elsewhere. Among others, the following Germans can be mentioned :

Wilhelm Muller, hailing from Frankfurt, leader of the cross-country expedition to Saldanha Bay (1653) and the trading expedition into the interior (1655), member of the Political Council.

Hermann Rehemagen (Remajenne), christened in Cologne, arrived at the Cape as a sailor in 1654. One of the first Free Burghers. Elected non-commissioned officer in the Citizen Force in 1660.

Georg Friedrich (Georgius Fredericksz) Wrede (Wreede), from Utze (Hanover), arrived at the Cape as a cadet in 1659. Volunteer member of Jan Danckaart's expedition to the north in 1660 , commander on Mauritius, merchant, commander on Mauritius.

Hieronymus Kruse, from Bielefeld. Undertook various journeys and in 1685 member of Simon van der Stel's well-known expedition into the interior. Promoted in due course to sergeant, sub-lieutenant, lieutenant and captain. In 1682 military commander of the Cape garrison. 
Johann Konrad von Breytenbach, from the Paltz, arrived at the Cape in 1671. Undertook trips to Hottentotsholland and False Bay. After the death of Pieter Hackius temporary military commander of the Cape. To St. Helena in 1673 .

Gabriel Dohmann, from Langensalza, sub-lieutenant in the Citizen Force in 1717, promoted to field cornet in 1718 .

Johannes Tobias Rhenius, from Berlin, sub-lieutenant in 1720 , leader of the expedition to Namaqualand in 1721 , captain in 1726 , military commander at the Cape from 1728 to 1739 .

Friedrich Christoph Lappenberg, from Bremen, non-commissioned officer, in 1721 acting commander of the D.E.I.C. post at Delagoa Bay.

Rudolph Jürgen Abell, from Hildesheim, sub-lieutenant in 1742 and then commander of the military post on the Salt River.

Johannes Friedrich Wilhelm Böttiger (Butger), from Kappel, in 1759 commander of the 2nd company of the Citizen Force infantry at the Cape.

Johannes Lorenz Lager Bestebier, from Offenheim, in 1748 captain of the Citizen Force cavalry.

Ludwig Christoph Warnecke (Wernicke), from Spangenberg, sub-lieutenant, adjutant, in 1755 captain of artillery, major.

Joachim Frederici, from Schwerin, sub-lieutenant (1750-1754).

August Friedrich Beutler, from Dinkelsbühl, sergeant (1747-1749), sublieutenant (1749-1754), leader of the well-known expedition along the east coast (1752).

Johann Konrad Zinn, from Sachsen-Eisenach, officer in 1786, later commander of the joint Citizen Force artillery.

Georg Konrad Küchler, from Hessen-Darmstadt, from 1785 to 1797 lieutenant of the artillery. As major and chief of the artillery, in 1795, commissioned by the Dutch supreme command, hands over an inventory, thus transferring the Cape public buildings and fortifications to the British officers Elphinstone and Bridges.

The above, incomplete list focusses the attention on a number of meritorious German officers and non-commissioned officers in the Dutch colonial military service, but the stay of various German regiments at the Cape during the period of Dutch management must also be borne in mind.

In the early eighties of the 18th century, the Cape garrison, as a result of the fourth war between England and the Dutch Republic (1780-1784), was reinforced by mercenary regiments from abroad. One of these was the Württemberg regiment commanded by Col. von Hügel. After the departure of the regiment for Batavia two of its officers, Maj. Bernhard Wilhelm von Dhen and Lt. Johann Heinrich Dolfuss, stayed on at the Cape.

After the return of the Cape Colony to the Batavian Republic in 1803, the Waldeck Batallion appeared at the Cape and one of its officers, Capt. Ludwig Alberti, was appointed commandant of Fort Frederick. We also know that there were Germans in the Batavian infantry of those days. Two of them were Lt. Phillippus Alberts from Saargemünd and Quartermasier Johann Jacob Wilhelm Hoffmann from Kassel. 


\section{THE GERMAN LEGION}

After the take-over at the Cape, in 1806, some fifty years passed before German soldiers again appeared in the Cape Colony.

During the Crimean War the British government considered the desirability of establishing a foreign legion to make provision for reinforcements in the theatre of war. With a view to this, some 2300 men, mostly Germans, were recruited and trained as infantry and light cavalry. They were commanded by Genl. Baron von Stutterheim.

However, the time factor prevented the so called German Legion from taking part in the war, and some place had to be found for the members after the disbandment of the Legion.

During the war Lord Panmure, who may be regarded as the father of the Legion, made arrangements for the Legion to be shipped to South Africa so that its members could be settled as military settlers in the eastern border area of the Cape Colony.

\section{CONDITIONS ON THE EASTERN BORDER OF THE CAPE}

As the white colonists trekked eastward and the Bantu gradually southward, the day was approaching that the two groups would clash.

About 1770 the first whites reached the Fish River where they found the Xhosa, a Bantu tribe. In 1870 the Cape government, for the first time in our history, put into practice the policy of territorial segregation, but the arrangement was not observed by the Xhosa.

Between 1779 and 1850 eight wars broke out in the border area. In the course of time a variety of border policies was tried out, the most important phases being the decision to erect military fortifications west of the Fish River, the establishment of a no man's land between the Fish and Keiskama Rivers and the annexation of the territory between the Fish and Kei Rivers. At this point, at the beginning of 1857, the members of the German Legion arrived at East London and were temporarily accommodated in camps.

About 2300 officers, non-commissioned officers and privates, some accompanied by their wives and children, came to our country at a time when the latest war on the frontier was still fresh in the minds of the colonists and the white frontiersmen, and the establishment of military settlements in the territory between the Fish and the Kei Rivers, known as British Kaffraria, was regarded as essential for the effective protection of the eastern frontier of the Cape Colony.

\section{CONDITIONS AND SETTLEMENT}

Commanded by Genl. Baron von Stutterheim the members of the Legion came to South Africa as a military organisation. Now they were known as German military settlers and, among other things, were liable to render seven years' military service. The officers would receive full pay for 3 years. In due course they would get land and money was made available for building houses.

The members of the three infantry regiments were sent out in three separate groups and were allotted settlements along the coast and near the mouth of the Keiskama. Others were settled near Fort Peddie and East London. 
Members of the 2nd regiment were responsible for the establishment of the settlements Potsdam, Berlin, Hanover, Marienthal, Wiesbaden and Breidbach, whereas other settlements, such as Greytown, Stutterheim, Keiskamahoek, Braunschweig and Frankfort, are reminiscent of the activities of the German military settlers of the 3 rd regiment.

Members of the cavalry joined the settlers at Greytown and Stutterheim and thus military and otherwise, considerably strengthened the frontier area. The then Cape government was fully justified to regard these German colonists as a buffer against the militant Bantu tribes on the frontier.

\section{DEPARTURE AND FURTHER DEVELOPMENTS}

As a result of military operations in India, more than a thousand German military settlers decided, in 1858, to leave South Africa and depart for the east where they were known as the Jäger Korps. In course of time some of them returned to our country.

In 1861 the German military settler group was disbanded as a military organisation, though, for the following three years, some ex-members still had certain military obligations towards the Cape government.

While initially the German settlements were regarded as pieces on a chessboard in British Kaffraria, the British parliament insisted on the annexation of the territory which today is known as the Ciskei. This was effected in 1865, the Kei River thus becoming the eastern frontier of the Cape Colony.

\section{MERITS}

The Cape government lauded the merits of the German military settlers and was fully justified to describe them as a rampart in the frontier area. In this regard they may be likened to the British settlers, as well as to the Voortrekkers from the Cape frontier area and other pioneers who rendered similar services to our country and nation.

From the ranks of the ex-members of the German Legion came such men as Capt. Carl von Brandis, first mining commissioner and special magistrate of Johannesburg. He was described as a man who possessed the necessary abilities to carry out his manifold duties successfully in a teeming mining camp which would develop into the biggest and richest urban area in the Republic of South Africa and would gain world fame. It was in these environs that Capt. Carl von Brandis, ex-member of the German Legion, made his mark.

\section{4}

\section{MAJOR R. F. W. ALBRECHT}

The name of Maj. Richard Friedrich Wilhelm Albrecht will always be linked with the military history of the Orange Free State. Born in Potsdam, he volunteered for service in the 4th battery of the Berlin Guards Field Artillery in 1876. During the Franco-Prussian War he saw action at the battle of St. Privat, the operations at Sedan and the siege of Paris.

In 1880 he joined the Free State Artillery Corps as captain. This corps was established by President Jan Hendrik Brand. Not only did he exert himself to step up the efficiency of the corps, but he also tried to improve the artillery- 
men's accommodation. The accommodation was cast in the German mould. He was also, to a great extent, responsible for the distinct German character of the uniforms and band of the Free State Artillery Corps. He also strove for the establishment of the Bereden Diensmacht or Gendarmerie which consisted of retired artillerymen. This excellent organisation remained under his leadership until 1896 when it was placed under the command of the Free State Commissioner of Police.

Presumably Maj. Albrecht also had a hand in the Free State Government's order for a number of Krupp guns in 1893.

During the Anglo-Boer War Major Albrecht, as commander of the Free State Artillery, took a hand in the siege of Kimberley and saw action at the battles of Belmont, Magersfontein and Modder River. While the Boer victory at Magersiontein was still compelling admiration through all the world, keen interest was aroused by the progress of the battle at Modder River which, against tremendous odds, was to follow soon afterwards. On the banks of the Modder Gen. Cronjé tackled a superior enemy, but after 10 days, on 27th of February, 1900, it all ended in complete encirclement and unconditional surrender. Maj. Albrecht and his artillerymen took part in this operation until his last gun was knocked out on 20th February.

His three 7,5 Krupp guns had to be given up, and together with artillerymen such as E. von Dewitz, K. von Heister and O. Augenstein, Major Albrecht was taken prisoner of war.

Until after the peace he was held in the camp at Green Point, Cape Town, returning to Bloemfontein after his release. When the Orange River Colony attained self-government, he became Serjeant-at-arms of the colonial parliament until he retired from office in 1910 when the Union of South Africa came into being.

When calling Major Albrecht's funeral to mind, there is ample proof that posterity has sounded the true worth of Major Albrecht's important contribution to our military system and traditions.

In November, 1926 a military cortege moved through the streets of Bloemfontein. The flag that draped Maj. Albrecht's hearse was the same that draped Gen. Christiaan R. de Wet's when this doughty warrior was borne to his grave.

Not alone was the sword lying on the Vierkleur a striking symbol of the operational readiness of the former model state between the Orange and Vaal Rivers, but also of the great merits of an officer who, in peace and war, had exerted himself continuously to promote and strengthen that readiness.

\section{THE SOUTH AFRICAN REPUBLIC}

The Germans played an important role in various fields in the military history of the South African Republic, the Voortrekker State north of the Vaal River. Sometimes it was individual efforts; at other times is was individual efforts within the framework of military organisations and the German military action in relation to the group. 
Curiously enough the German contribution in the military field began with the construction of a fort which was intended not only as a military, but also as a spiritual stronghold. This fort was Fort Wilhelm which was renamed Fort Merensky a few years ago.

\section{FORT MERENSKY}

The history of this remarkable stone fort, initially known as Fort Wilhelm, brings to mind the activities of the Berlin Mission Society and one of its missionaries, the Rev. Alexander Merensky.

In 1865 the latter bought a farm near Middelburg, Transvaal, and founded there the missionary station Bothsabelo, i.e. sanctuary. To protect the station and the Bantu converts living there against attacks, it was decided to erect a stone fort. This stronghold was built partially under the supervision of the Rev. Merensky. It is a magnificent example of Sotho architecture, but it also displays touches of European influence which may undoubtedly be attributed to the Rev. Merensky.

Thanks to the joint efforts of the Berlin Missionary Society, the Simon van der Stel Foundation, the Hans Merensky Trust, the Middelburg Town Council and other interested parties, the fort, now known as Fort Merensky, was restored and ceremonially opened on 17th November, 1962.

On 17th March, 1967 Gen. R. C. Hiemstra, S.S.A., S.M., C.G., S.A.D.F., unveiled the plaque of the Historical Monuments Commission at the fort and said:

Thus at a time when this fort was built, it was a spiritual and military sanctuary, a sure defence. Today we do not build forts any more, but we are still building a sure defence. Our building materials are not the stones and rocks from our soil, but the things that our nation brings about with its mind, its common sense and unwearying diligence. Of its kind, Fort Merensky is a unique example of fortification in South Africa and, what is more, through the change of designation the name of a German missionary will forever be linked with this particular building.

\section{CAPTAIN RIEDL AND CAPTAIN VON SCHLIECKMANN}

Capt. Otto Riedl was the first instructor of the newly established Transvaal Staatsartillerie and under his guidance the Transvaal artillerymen became acquainted with the handling of some Krupp mountain guns. Still under Riedl they also took part in the military expedition against Sekukuni and in the war of 1880-1881.

Another well-known German officer was Capt. Conrad Heinrich Hans von Schlieckmann, proud bearer of the Iron Cross which he gained during the Franco-Prussian War (1870-1871). Commanding a volunteer corps, he entered the Sekukuni War and was killed in action on 17th November, 1876.

land.

Capt. von Schlieckmann made the supreme sacrifice for his new father-

We also call to mind Capt. H. T. Schröder who established the Schutzenkorps at Rustenburg during the Sekukuni War. Other indications of German influence are the movable iron forts which were bought in Germany and set up in the Eastern Transvaal during the eighties. Furthermore Gen. P. J. Joubert, the Transvaal Commandant General, also visited the Krupp factory at Essen. 
It was during this period that Adolf Schiel, later to be Lieutenant-Colonel and author of 23 Jahre Sturm und Sonnenschein in Südafrika started his colourful career in the country of State President S. J. P. Kruger.

\section{LT.-COL. ADOLF F. SCHIEL}

Born in Frankfurt (1858), Adolf Schiel served for some time in an infantry regiment and then, for three years, was member of the Duke of Brunswick's Black Hussars. In 1878 he appeared in Natal after which he did clerical work in the Eastern Transvaal where he also worked as postal agent and collector of import duties. After acting for some time as political adviser to Dinizulu, the Zulu chief, Schiel was appointed teacher of the Rijdende Artillerie en Politie in Pretoria in 1888 and promoted to captain in 1889 . Then he returned to the administrative service, this time as native commissioner of Spelonken.

April 1894 saw his appointment as acting administrator of the Rijdende Artillerie en Politie and in this capacity he took part in various military expeditions against insurgent Bantu tribes. Having again taken up his administrative duties at Spelonken, he was appointed first chief of the Prisons Department in the Republic in April, 1896.

In the course of the same year the Government decided to construct a fort at Johannesburg to prevent a possible repetition of the local riots which had occurred during the notorious Jameson Raid.

The distinction of being nominated as a member and executive of the official building commission was conferred on inspector Schiel. In 1897 he was appointed commandant of the fort. In 1897 this appointment was extended for one year, while at the same time Commandant Schiel received the military rank of Lieutenant-Colonel.

On 12th June, 1899, Lt.-Col. Schiel handed over the completed and partially armed fort to the government. One month later he resumed his duties as chief of the Prisons Department at Pretoria. Soon afterwards, because of the threatening war, he exerted himself to raise a commando which would fight on the side of the Transvalers.

\section{GERMAN EXPERTS AND THE TRANSVAAL FORTIFICATION PROGRAMME}

The treacherous Jameson Raid of 1895 and the rebellious spirit that prevailed among the Johannesburg Uitlander population were mentioned in passing. This led to the government's decision in 1896 to build a fort in Johannesburg. While the fort was being designed by the Transvaal Department of Public Works, in co-operation with the future fort commandant, Lt.-Col. A. Schiel, both the German engineer O. von Dewitz and his countryman H. C. Werner played an important role in designing and building three of the four forts around Pretoria. These forts were intended to protect the seat of the Republican government against a possible military threat which might rise from a possible repetition of the Jameson Raid.

Apart from Werner's company completing forts Schanskop, Wonderboompoort and Klapperkop and two fortified magazines at Pretoria, Von Dewitz devised a grandiose plan for providing the Republic's strategically important approaches with formidable fortifications. This plan never realised but to this day the restored Fort Klapperkop - now known as the Military Museum Fort Klapperkop - bears testimony of the important German contribution towards the security of Pretoria, i.e. the centre of the South African Republic (Zuid-Afr:kaansche Republiek). 
During the eighties, while A. Schiel helped temporarily, both administratively and educationally, in building up the forerunner of what, in the course of time, was to become the famous Staatsartillerie, the following German officers were members of the officers corps during the Jameson Raid and the AngloBoer War.

Capt. Heinrich Christian Wilhelm Grothaus from Dortmund, arrived in the Zuid-Afrikaansche Republiek in 1895, appointed artillery instructor in 1897 and attached to the 1st battery of the Staatsartillerie. Capt. Grothaus went to the Natal front in 1899 and remained in the field until the end of the war.

Lt. Friedrich Wilhelm von Wichmann, before his arrival in the Transvaal, was Lieutenant in the 1st Guards Infantry Regiment at Potsdam. In 1897 he was appointed 2nd Lieutenant in the Transvaal Garrison Artillery, Johannesburg, and subsequently posted to the 3rd battery of the Staatsartillerie in 1899. In this capacity he saw action in the battles of Dundee, Modderspruit and Colenso. Later he joined Gen. Chris Botha on the Highveld and fought till the end of the war.

Capt. Dr. Johann Otto Hohls, the son of a German missionary in Natal, studied medicine at the universities of Strassburg and Heidelberg, returned to our country in 1889 and ten years later was commissioned captain and first medical officer of the Transvaal Staatsartillerie. Capt. Hohls fell during the battle of Modderspruit while he was treating wounded Boer warriors. Soon afterwards he was buried in Pretoria with full military honours.

\section{GERMANS DURING THE ANGLO-BOER WAR}

As it was becoming more and more obvious that war was inevitable, Lt.-Col. Schiel even more exerted himself to raise a German commando to defend the rights of the Boers.

\section{JOHANNESBURG}

After a German organising committee under chairmanship of Dr. F. X. Elsberger had been established in Johannesburg, a mass meeting was called for 23rd August, 1899. On this occasion Lt.-Col. A. Schiel was chairman and the following proposals were accepted: The committee was instructed to offer its services to the Transvaal government. In the event of war, the government should be approached with a view to recognising the sympathetically inclined Germans as a separate corps. At this meeting the Deutscher Verband was established. Among other persons Dr. F. X. Elsberger (chairman), Count Harra von Zeppelin and 2nd Lt. H. C. W. Grothaus from the Staatsartillerie were members of this committee.

\section{PRETORIA AND BLOEMFONTEIN}

On 31 August, 1899, Lt.-Col. Schiel called a meeting at Pretoria on which occasion a local branch of the Deutscher Verband was established under chairmanship of surveyor Hans Ulrich von Quitzow. Also in Bloemfontein the Germans were called upon to assist the Boers in the event of war and the same day on which the meeting was held, the Transvaal government not only accepted the Germans' offer, but at the same time acceded to their request to establish their own corps. 


\section{ORGANISATIONAL ACTIVITIES}

On 1st September, 1899 the Deutscher Verband started organising to raise a commando or corps which could assist the Boers in the approaching war. Members of this military unit would be all naturalised Germans who were liable for military service, whereas those not yet naturalised might join as volunteers. While the corps commandant would come under the Commandant General or a Combat General the members of the corps would elect their own officers. These appointments would be confirmed by the government. The officers would take the oath of office before the representatives of the Government and other ranks would take the oath of allegiance before the commandant. It was further laid down that the government would equip the commando and that neither servicemen nor volunteers would get pay.

At the beginning of September the Johannesburg branch of the Deutscher Verband elected Lt.-Col. Schiel as commandant and A. W. Tischmer and E. P. Büttner as field cornets. In Pretoria Hans Ulrich von Quitzow was appointed field cornet and Paul A. Krantz assistant field cornet. The Johannesburgers called their organisation the German Commando, whereas the Pretorians preferred the designation the German Corps.

Support for this movement came from Heidelberg, Krugersdorp and Soutpansberg. At the same time the German example fired the enthusiasm of other naturalised citizens and citizens of other states. Ex-Dutchmen, Dutch subjects, Irishmen, Belgians, French and Scandinavians, among other groups, followed the German example and established military units of their own.

In the meantime Lt.-Col. Schiel had also organised about 120 Afrikaners, i.e. members of the Transvaal Prisons Department, under chief warden Potgieter into the Afrikaner section of the German commando in Johannesburg. Dr. Elsberger initiated the establishment of an ambulance section.

Lt.-Col. Schiel organised his staff as follows: Capt. C. Weiss, Capt. Count Harra von Zeppelin, Lt. George Badicke, Lt. Otto von Albedyll, Capt. Adjt. Thomas Chalmers Robertson (Afrikaner section).

On 19th September, 1899 the following officers took the oath:

For the Johannesburg detachment: Adolf Friedrich Schiel, lieutenantcolonel, commandant of the German commando; Thomas Chalmers Robertson, captain adjutant to commandant Schiel; Count Harra von Zeppelin, captain, special staff officer; Georg Badicke, lieutenant, special staff officer; Otto von Albedyll, lieutenant, special staff officer.

For the Pretoria detachment: Hans Ulrich von Quitzow, field cornet, staff officer; Adolph Paul Krantz, special assistant field cornet. The establishment of the Johannesburg detachment came to about $500 \mathrm{men}$, and in Pretoria some 100 corps members were ready to take up arms.

The Johannesburg detachment had 500 Mausers at their disposal and 150 Martini Henry rifles were issued to the Pretoria members. The Government provided commando members with horses, wagons, tents, supplies, etc., but a shortage of horses and equipment prevented all 600 men from being sent to the front at the same time.

\section{TO THE NAT AL FRONT}

On 1st October, 1899 the Johannesburg detachment entrained at Johannesburg, for Standerton. The next day they marched to the Free State border. A small number remained at Platrand while the bulk of Commandant Schiel's 
corps marched with the Johannesburg commando in the direction of Bothaspas, where, under Gen. J. H. M. Kock, they formed the right wing of the Transvaal main body on the Transvaal-Natal border.

In the meantime the Pretoria detachment had held a parade on Church Square, Pretoria, on 2nd October and on 7th October some 130 men from this detachment under Field Cornet von Quitzow departed from the Transvaal capital for Sandspruit. At the time of Field Cornet von Quitzow's arrival at Sandspruit, Capt. Robinson, with some 115 men, i.e. the Afrikaner section of the German Commando, was already on his way to join Commandant Schiel.

At this point the total establishment of the German commando concentrated near the Transvaal-Natal border was approximately 530 of whom about 275 were mounted.

On 10th October Field Cornet von Quitzow and his men were marching for Utrecht after being placed under the command of Gen. Lucas Meyer. By carrying out this order of the commandant general, Gen. P. J. Joubert, the German commando split into two as a result of a quarrel between Commandant Schiel and special Assistant Field Cornet Adolph Paul Kranz. In this manner, according to Mr. Melt van Niekerk in his thesis Adolf Schiel en die Duitse Kommando, two separate German corps came into being. Each set out on its own direction to engage the enemy.

While the two corps and the Boer forces on the Transvaal-Natal border were biding the outcome of the final stages of the diplomatic struggle between the Republics and the British Empire, further German military and civil organisational activities were continued in Johannesburg and Pretoria.

On 9th October, 1899 the Transvaal government handed the ultimatum to the British government. The demand that British troops had to be withdrawn from the frontier area within 48 hours was ignored and on 11th October war broke out.

\section{ELANDSLAAGTE}

On 12, 13 and 14th October, 1899, the Transvaal commandos invaded Natal from three different directions and on the 16th October a council of war was held at Newcastle.

Among other things it was decided that Gen. Kock with the Johannesburg commando, under Commandant Ben J. Viljoen, some 100 Free Staters, the German corps under Commandant Schiel and the Dutch corps under Commandant J. P. la Grange Lombard would occupy Biggarsbergnek to cut the communication between the British garrisons at Ladysmith and Dundee. On the same occasion Gen. Lukas J. Meyer was ordered to attack Dundee from the east. The Germans under Field Cornet von Quitzow were not involved in this operation because they arrived on the scene too late. Gen. Kock deviated from the war council decision and marched to Elandslaagte where he occupied defensive positions in very unfavourable terrain.

There Gen. Kock's force of 150-1000 men were attacked and pulverised by a superior British force of 3500 men. Both Gen. Kock, heavily wounded, and Commandant Schiel were taken prisoners.

Gen. P. J. Joubert ordered the remaining corps members to Johannesburg. There they were given the choice either to join the local special police corps or fill up their depleted ranks and raise a reorganised corps. 


\section{REORGANISATION IN THE ORANGE FREE ST ATE}

In Johannesburg the reorganisation of the corps was tackled without delay and 12 days after the battle of Elandslaagte Lt. Otto von Albedyll, with 288 men, departed for Colesberg where, under Gen. Hendrik Schoeman, they were instructed to guard the Orange River bridge.

After Lt. von Albedyll had been succeeded by Field Cornet F. Brall, more corps members as well as ambulance personnel departed from Johannesburg for the Orange Free State.

\section{ADVENTURES OF VON QUITZOW'S CORPS}

As was mentioned in passing, Von Quitzow's corps was not involved in the battle near Dundee on 20th October, 1899. The corps had gone with Gen. Meyer's commando's to Ladysmith. Thereupon the corps saw action in various battles in Natal and the corps members distinguished themselves especially in the assault of Platrand (6/1/1900) and the famous battle of Spioenkop (24/1/1900).

During these operations Field Cornet von Quitzow was not in command of the corps any more. He had resigned in December 1899 and was succeeded by Commandant Adolph Paul Krantz which Richard Runck and Fritz Schultz, respectively, served as field cornet and assistant field cornet under the new commandant. The German ambulance under Dr. Elsberger, temporarily detached to Comdt. Ben J. Viljoen's reorganised commando, returned to the corps in November 1899.

In January 1900 various efforts were made to unite the German corps in Natal and the one in the Orange Free State under one recognised leader. These efforts failed. The Natal corps was weakened as some members had joined Boer commandos and a further fifty, under Field Cornet Runck, departed for the Colesberg front to link up with Comdt. Brall at Springfontein.

Before Comdt. Krantz's corps was weakened in this manner the members saw the relief of Ladysmith and in March 1900 the mounted men were placed under command of Combat Gen. J. Ferreira at Helpmekaar. During the evacuation of Natal the infantry lost contact with the mounted members of the corps. As a result of all these circumstances Comdt. Krantz had only 70-90 corps members at the beginning of April, 1900.

\section{FROM THE ORANGE FREE STATE TO PRETORIA}

As British pressure was increasing on all fronts, Field Cornet Runck and his men, as was mentioned earlier, awaited and joined the German corps under Condt. Brall at Springfontein.

On 2nd April, 1900 Comdt. Brall and his men went to Sannaspost and from there to Brandfort where they came under Gen. J. H. de la Rey's command.

During the withdrawal through the Orange Free State the corps saw action in various battles, inter alia, in the battle of Vetrivier $(5 / 5 / 1900)$, while, on 11 th May, they helped to cover the withdrawal of the Boer forces from Kroonstad to the Vaal River.

They were among the last to leave Johannesburg on 31st May, 1900.

During a skirmish, Comdt. Richard Runck, who succeeded Comdt. Brall at the beginning of the month, was captured by the enemy.

His Adjutant, Lothar Kunze, Field Cornet H. D. Meyer and part of his corps members escaped from the superior British forces on this occasion. 
A part of the Corps under Comdt. Lothar Kunze continued the strife, whilst others under Field Cornet H. D. Meyer established a separate German Scout Corps.

Under these circumstances the depleted German Corps of Comdt. Lothar Kunze trekked northwards through the threatened Pretoria and after the capture of the city on 5 June, 1900, took part in the battles east of the evacuated capital. They took part in battles at Tygerpoort as well as at Donkerhoek $(11 / 6 / 1900)$.

\section{TO THE BITTER END}

It is known that the German Reconnaissance Corps under Field Cornet H. D. Meyer rendered valuable service to Gen. Louis Botha after the capture of Pretoria, whilst the remaining members of Comdt. Kranz's corps, now under the leadership of Dr. R. Krieger, a former surgeon from Carolina, distinguished themselves. Gen. Botha appointed Dr. Krieger as Commanding Officer over all members of the foreign corps who participated in the military operations east of Pretoria.

Amongst others they participated in the bloody battle of Berg-en-Dal, whilst part of them, pressed against the western border of Portuguese East Africa, had to lay down arms with part of the Boer comrades in Portuguese territtory.

Others, as members of various, Boer commandos remained in the field, until the Treaty of Vereeniging brought an end to a prolonged, titanic, struggle, others on the other hand waited in British prisoner of war camps for the day of liberation .... .

One of the latter was Comdt. Adolf Schiel, one of the former was Comdt. Lothar Kunze, the last commander of the German Corps.

For them and above all for those members of the German Commando of 1899 and the subsequent German Corps which lie buried in South African soil, the following words of State President S. J. P. Kruger no doubt apply:

There are perhaps many of you whom I will never see alive again, but I can assure you that you have won the thankful hearts of the Boers, and you shall have a place in the history of the Boer people.

\section{6}

\section{SOUTH-WEST AFRICA}

From South African soil the scene now shifts to South-West Africa with her broad steppes, her richly-ravined mountain ranges and its waterless Namib, to the land of the Bushmen, Nama-Hottentots, Bergdamas, Ovambo tribes, Hereros, Oorlams and Bastards.

\section{GERMAN MISSION FIELD}

This territory was first set foot on from German side when Rhenish missionaries during 1842 followed in the trails of hunters, prospectors and traders to undertake missionary work in Namaland, among the Hereros and in Ovamboland. 
During 1863 the Rhenish Missionary Society requested the German Government to protect its missionaries in South-West Africa. This was the first opportunity to establish German authority in this area, but the statesman Bismarck declined the request.

\section{EXPANSION OF THE SPHERE OF INFLUENCE}

The expansion of the German sphere of influence in South-West Africa dates from 1884, when Bismarck officially placed the property rights of the Bremen trader F. A. E. Luideritz from the mouth of the Orange River to the 26th degree latitude under the protection of the German Empire.

With South-West Africa now within the German sphere of power and aided by the German plenipotentiaries Dr. Nachtigal, Reichskommissar Dr. Heinrich Göring and Dr. Büttner, protection treaties were signed on behalf of the Deutsche Kolonialgesellschaft whereby Germany established herself firmly in South-West Africa.

Due to economic reasons the German Government, in analogy of the colonial policy followed at the time by England and France to develop colonial territories by means of giant trading companies, granted extensive powers to the Deutsche Kolonialgesellschaft. By implication this meant that South-West Africa was governed by its own officials.

In this manner South-West Africa was not only exploited in the beginning by the Deutsche Kolonialgesellschaft, but the trading company was in fact also responsible for maintaining peace and order in the territory.

\section{EST ABLISHMENT OF THE GERMAN AUTHORITY}

The result of this realisation was that Landeshauptmann Kurt von François, founder of Windhuk and Swakopmund, builder of the Alte Feste and the Wilhelmsfort, landed in 1889 at Walvis Bay with a small military force from Togo to give military assistance to the handful of officials in Otjimbingwe as well as the signatories of the protection treaties.

To increase the numbers of this nucleus, Bastards were recruited as mercenaries for military and police duties.

\section{LANDESHAUPTMANN VON FRANÇOIS}

Only once during 1893 did this founder of white civilisation in German South-West Africa operate in the defence of the Hereros at Hornkranz against the disturber of the peace, Hendrik Witbooi, the Nama chief leader of Gibeon. He was recalled to Germany during 1894, to be succeeded by Maj. Theodor Leutwein as Governor and supreme commander of all troops, henceforth known as the Imperial Schutztruppe i.e. the protection force.

\section{GOVERNOR LEUTWEIN}

Under the regime of Governor Leutwein (1894-1905) Hendrik Witbooi was subdued, also the uprising of the Swartboois at Fransfontein and Sesfontein in the Kaokoveld as well as that of the Bastards at Grootfontein in the south was suppressed. Peace came in 1896 and lasted until 1904. During this period there was peaceful development of the country. 


\section{SUPPRESSION OF UPRISINGS}

The supremacy of German protection limited the natural expression of freedom which was inherent in the nature of the Nama and the Hereros. They longed for bygone days, this yearning prevaded the atmosphere with unrest.

This explosive situation erupted towards the end of 1903 when the Bondelswarts, a Nama tribe towards the north of Warmbad, revolted against the German authorities.

Governor Leutwein proceeded to the south personally to subdue the leaders Morris and Morenga and to restore peace and order.

The concentration of German protection troops in the south created a favourable atmosphere for the restless Hereros to follow the example of the Namas. During the subsequent Herero deeds of violence no less than 123 German farmers suffered violent deaths, whilst those who escaped, took refuge in military forts at Windhuk, Seeis, Omaruru, Outjo and Grootfontein.

The commander of the German troops at Omaruru, Hauptmann Franke, received orders to give immediate armed assistance from Namaland to the besieged places. On 15 January, 1904 he executed this order and started his hurried march to the north. Assisted by Leutnant von Zülow of Swakopmund, Kapitän Gudewill and Kapitän Gygas, of the German man-of-war Habicht, he relieved Windhuk, Okahandja and Omaruru in succession.

After the peace at Kalkfontein which terminated the Bondelswart uprising on 27 January, 1904, Governor Leutwein joined his forces in the north. From Okahandja he launched in the same year attacks against the Hereros at Otjihinomaparero, Ovikokorero, Ongandjira and Oviambo. This offensive, with great loss on his side, resulted in the gradual repulsion of the Hereros to the north. Repulsion did not, however, result in the expected submission. The Waterberg became the Thaba Bosigo of the Hereros.

Governor Leutwein who was inclined to reach a peaceful settlement of the strife by negotiation, had to make way at this stage for Gen. Lothar von Trotha, who succeeded him as supreme commander.

The latter, on orders of Emperor William II, did not follow the same policy as his predecessor. In instructions from the Emperor submission of the Hereros had to be achieved by force and the consequent demoralising effect of submission to German supremacy.

Large scale preparations were made for the final assault on the Hereros, whilst reinforcements arrived at Swakopmund.

On 11 August, 1904 the attack was launched. At Hamakari the German troops executed a pincer movement, but the staunch resistance of the Hereros left a breach in the ranks of the encircling troops whereby the whole Herero nation with its disintegrated tribal system was no longer a militant factor with which the German authorities would have to contend. Gen. von Trotha returned to Windhuk with his staff leaving Maj. von Mühlenfels to guard the frontier.

During July, 1904 he surprised a number of troops in Davingnab and in October Hendrik Witbooi declared war against the Germans. German reinforcements were rushed to the scene and in December, 1904, and January, 1905, the Namas, although not decisive, suffered severe defeats at Naris and Gochas. Contrary to Gen. von Trotha's expectations, the Namas did not unite. 
Hendrik Witbooi sought the protection of the barren Kalahari from where he launched a surprise atttck against the German troops. At Vaalgras, in the vicinity of Keetmanshoop, he was wounded in a skirmish, which despite his escape, caused his death. His successor, Samuel Isaak, on order from Hendrik, submitted to the Germans in 1905.

The Nama leader of Gochas and Hoachanas, Simon Koper, Kornelius of Bethany and Johannes Christiaan of Warmbad as well as Morenga and Morris of the Bondels in the south east of Namaland continued the strife. The Bondels were only subdued on 25 December, 1906, whilst Simon Koper remained a thorn in the flesh of the German troops for a further two years.

\section{SOUTH-WEST AFRICA UNDER GOVERNOR VON LINDEQUIST}

As regards the Hereros, their nomadic bands remained a nuisance to the German troops.

Thousands were, however, captured and Dr. Friedrich von Lindequist, who became Governor during 1905 in succession to Gen. von Trotha, in an attempt to find a peaceful solution to the problem, placed the captured Hereros under the protection of missionaries in three concentration camps.

Through the efforts of the missionaries approximately 12000 further neglected and famished Hereros were added to the prisoners, whereby many were saved from certain death. Eventually they were transferred to prison camps at Windhuk, Okahandja and Swakopmund, from where they were employed as labourers over the length and breadth of the country. This measure created a drainage on the camps, which in turn led to the repeal of martial law on 13 March, 1907.

The only discord in the song of peace was Simon Koper of Gochas, who persisted in causing unrest in the land through his plundering raids. On 16 March, 1908 Hauptmann Friedrich von Erckert offered refuge to the dove of peace in Namaland, when at the cost of his own life subdued this recalcitrant Nama captain at Seatsub.

\section{MONUMENTS}

From Waterberg in the north to Warmbad in the south, even as far as Gochas on the Auob, there are today fitting and worthy monuments testifying to the 88 battles against the Hereros and the 295 engagements with the Namas, in which 179 officers and 2169 other ranks lost their lives in the taming of the hinterland.

\section{RECONSTRUCTION. WAR CLOUDS}

During the period following 1907 much was achieved in the reconstruction of the country under the governorship of Bruno von Schuckmann (19071910) and Dr. Theodor Seitz (1910-1915).

With the military operations against the Namas and the Hereros as something of the past, economic and cultural progress enjoyed preference over military affairs.

War clouds were, however, gathering over Europe; few knew or even surmisc.d that South-West Africa would be involved in this military epic. Contrary to general expectations in Berlin and Windhuk, South-West Africa also became a target of British Imperialism at the outbreak of the war in 1914. 
Luderitzbucht and Swakopmund were to be occupied and the radio station at Windhuk seized. On 19 August, 1914 the Union Government accepted responsibility herefore and on 21 August, 1914 the first shots were fired at Schuitdrift on the Orange River.

As against the more than 60000 men of the Union, the German commander Oberstleutnant von Heydebreck, later succeeded by Major, afterwards Oberst Franke, could rely on at the most 10000 men.

In the light of the foregoing there was no question of offensive action on the German side and the preconceived plan was from the beginning the protection of the frontiers and the defence of the land, whilst all means were to be employed in the struggle to delay capitulation. In this process as many as possible of the enemy forces were to be held down in the hope that a decisive battle in Europe would offer relief to the defenders.

Embarking at Cape Town Brig.-Gen. (later Sir) H. T. Lukin landed at Port Nolloth to operate on the southern border. Col. P. S. Beves was also on his way from Cape Town to overpower Luderitzbucht, whilst Lt.-Col. S. G. Maritz gathered his forces at Upington and Kakamas to concentrate on the south eastern border.

The destruction of the radio station and landing equipment at Swakopmund was carried out by a British naval bombardment.

Gen. Lukin's advance was seriously delayed by the defeat of Lt.-Col. R. C. Grant on 26 September 1914 at Sandfontein by Von Heydebreck as well as by the intervention of the Armed Protest or Rebellion.

\section{THE ADV ANCE TO WINDHUK}

Meanwhile the strategic value of Windhuk as the nucleus of the German offensive was realised and the capture thereof given prioritiy. In this connection Walvis Bay and Swakopmund were regarded as without doubt to be the most important starting points.

During February, 1915 the Union troops were deployed as follows:

(a) The northern force led by Gen. L. Botha and with Brig.-Gen. Sir Duncan McKenzie as commander with a line of advance Luderitzbucht to Aus and further east: (b) the eastern force under Col. C. A. L. Berrangé who had advanced from Kuruman to Keetmanshoop and (c) the southern force under the command of who was to become Lt-Gen. (later Sir) Jacobus L. van Deventer with a line of advance reaching from Upington through Sandfontein and Warmbad to Keetmanshoop.

From Luderitzbucht, from across the Orange River and from the east the Union troops advanced against the German forces who gradually with their retiring tactics fell back to Gibeon. On 27 April Maj. von Kleist was driven back from his provisional assembly area at Gibeon station in the direction of Mariental by Gen. McKenzie.

The retiring Maj. von Kleist was, however, confronted with another problem, namely that his line of retirement to Rehoboth was out as a result of the Bastard revolt there. This compelled him to retire east of Rehoboth and Windhuk to the north.

Meanwhile the advance from Swakopmund commenced on 23 February, 1915. The battles at Riet, Pforte and Jakkalswater were the prelude to Gen. Botha's offensive against Karibib and Windhuk, which were respectively cut off on 6 and 12 May, 1915 as being occupied. 


\section{THE GERMAN TRIANGULAR POSITION}

The German forces selected as the end of their line of retirement the triangle formed by Otavi, Grootfontein and Tsumeb, which included the farms Gaub and Khorab, which offered abundant water and grazing. Governor Seitz and his officials were at this stage already at Grootfontein.

The idea behind this strategy was to prevent the advance guard of Union troops, after their march through the barren region between Omaruru, Otjiwarongo and Otavi, from penetrating the occupied triangle. Should the defence appear hopeless, the reservists on German side could be discharged and the remaining nucleus of professional soldiers could make an attempt to penetrate to the north to join up with Gen. von Lettow-Vorbeck in East Africa.

In order to launch an attack against the German troops in their last stronghold in the north and to force a surrender by means of a pincer movement, Gen. Botha formed 3 army divisions.

Gen. C. J. Brits who was appointed commander of the left flank, had to advance to Namutoni on the Etosha Pan via Omaruru, Okambahe and Outjo, whilst Gen. M. W. Myburgh, the commander of the right flank received orders to advance along the two major roads to Waterberg and to occupy Grootfontein.

The centre columns under the direct command of the Commander-inChief Gen. Botha were to advance on the main road next to the railway line and launch a frontal attack. Between Gen. Myburgh and the centre columns Gen. H. W. N. (Manie) Botha, whilst keeping in touch with the forces on either side, was to advance on the east side of the railway line to Omburo.

After reaching their respective goals, Generals Brits and Myburgh, in collaboration with the Commander-in-Chief, were to encircle the enemy.

\section{KHORAB}

The advance commenced on 18 June, 1915.

The German forces were no match for this large scale offensive. Otavifontein and thereafter Otavi were mastered. Namutoni and Tsumeb were occupied. The pincer movement tactics of the Union troops were successful - the German forces were encircled at Khorab.

The uselessness of defending this position was realised by the German supreme command. Negotiations were started; a truce followed and on $9 \mathrm{July}$, 1915 the Peace of Khorab brought peace to the war afflicted South-West Africa.

A total of 3497 troops of the Schutztruppe laid down their arms under honourable peace terms, whilst 1331 of their comrades had been killed in action. A total of 4740 members of the German forces were captured or forced to surrender by the Union troops during the final stages of the offensive. The losses on the side of the Union of South Africa were as follows: Killed in action 88, died of wounds 25 , died as a result of sickness and accidents 153 and wounded 263.

The German reservists were discharged and the professional soldiers interned at Aus.

The Government was taken over by military officials under Sir Howard Gorges. Dr. Seitz settled at Heusis near Windhuk.

The departure of Dr. Seitz and his officers and men during 1919 terminated the share of the Germans in the military history of South-West Africa. 
As regards the Republic of South Africa and its ablebodied citizens in the various arms of the force, it is a well-known fact that descendants of respective generations of German immigrants today occupy honourable positions within the ranks of the South African Defence Force. fatherland.

They are in common with their fellow citizens, jutsifiably proud of our

They are prepared and ready.

They are prepared as South Africans to offer the highest sacrifice in the hour of need!
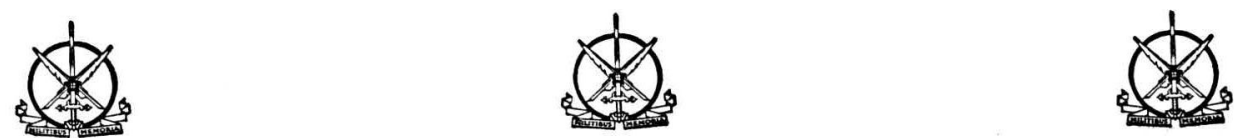


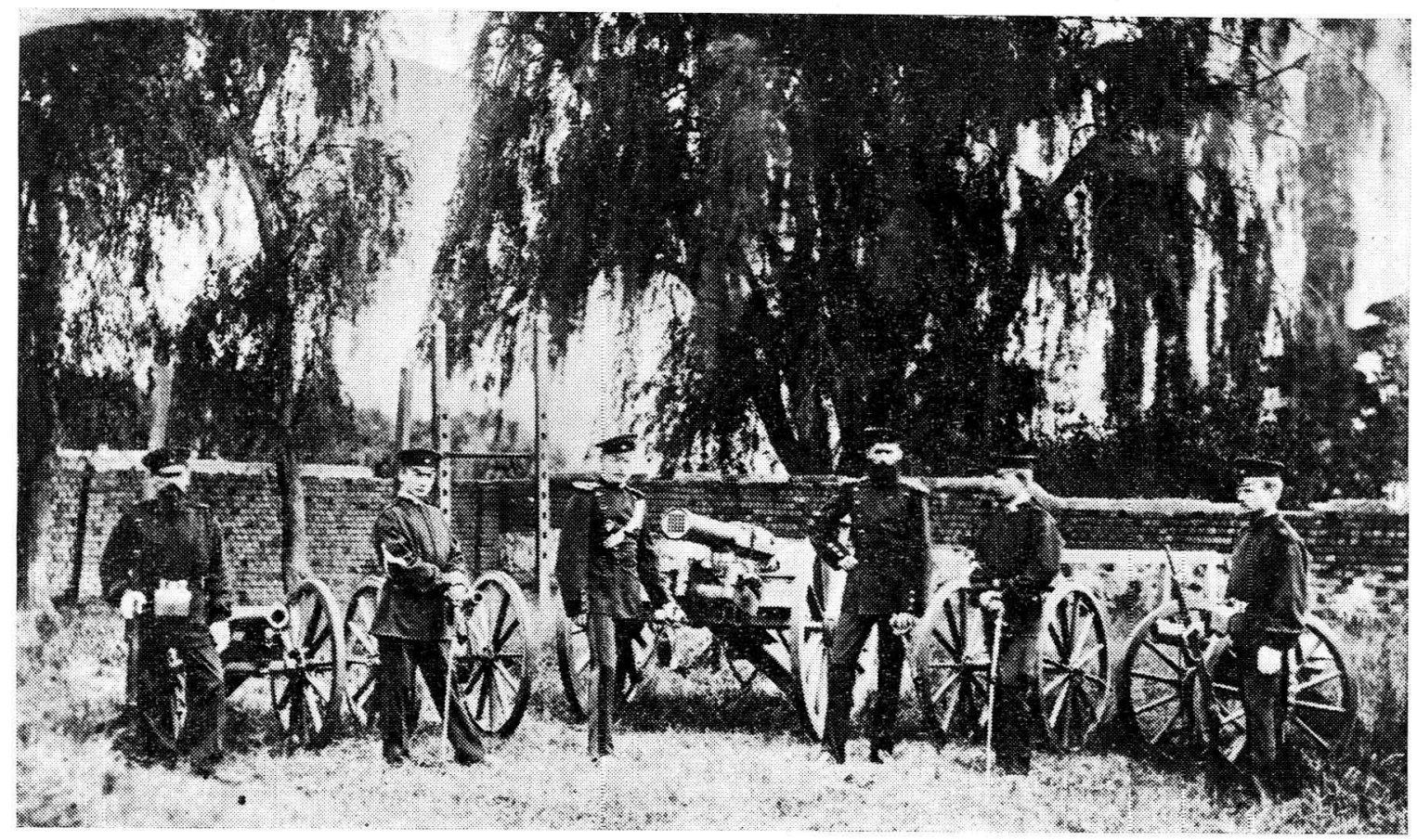

Transvaalse Staatsartillarie in die sewentiger jare met kapt. O. Riedl as bevelvoerder.

Foto: Sentrale Fototegniese Inrigting S.A.L.M., L.M.B. Swartkop/M.H.A.D.

Transvaal State Artillery during the seventies with Capt. O. Riedl as Officer Commanding. Pho:ograph: Central Photographic Establishment S.A.A.F., A.F.B. Swartkop/M.H.A.S.

Transvaalsche Staatsartillerie während der siebzigen Jahro mit Hauptmann O. Riedl als Kommandant. Photo: Zentrale phototechnische Anlage S.A.A.F., A.F.B. Swartkop/M.H.A.D.

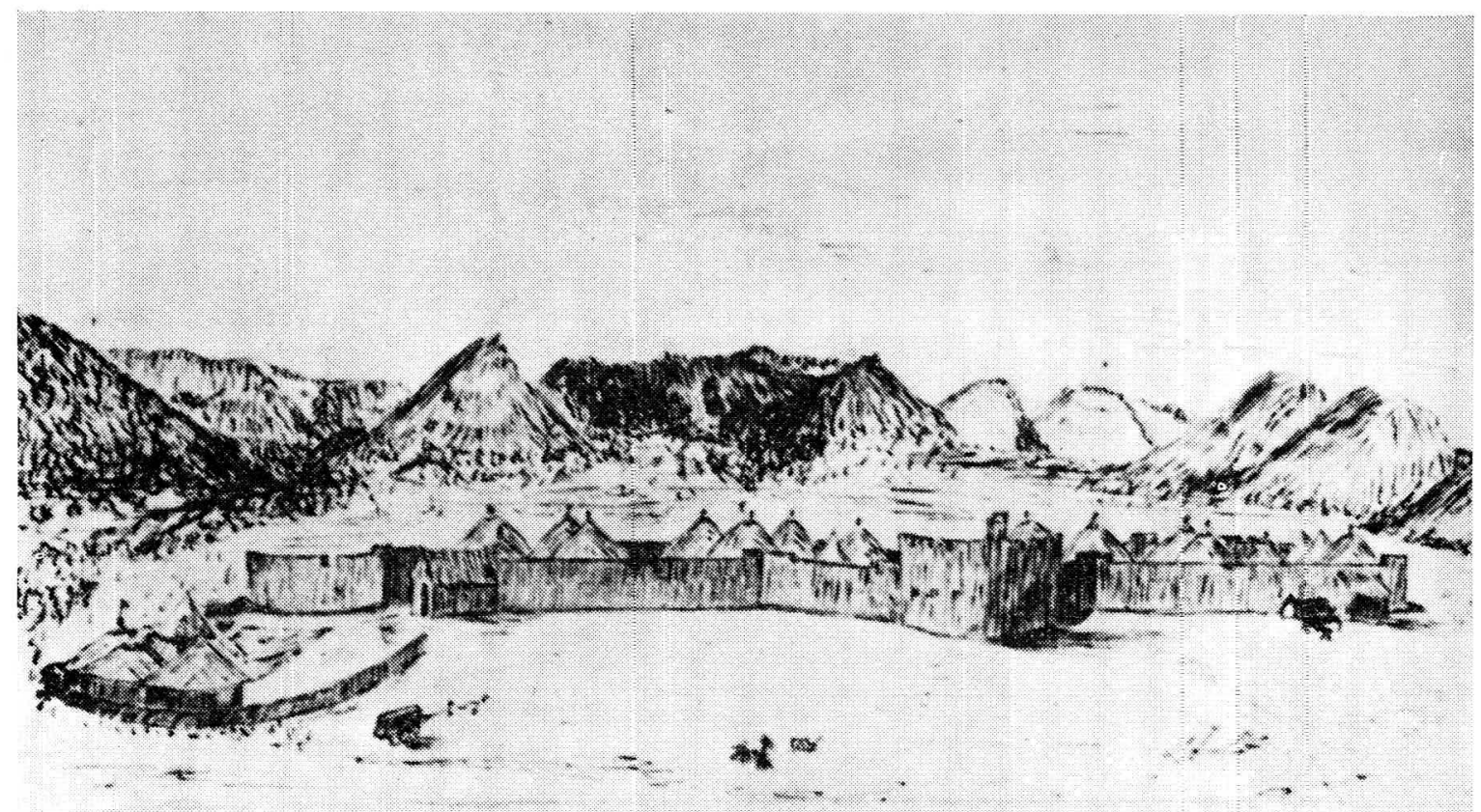

Fort Mamabule, Sekukuniland, Transvaal (1878).

Foto: Sentrale Fototegniese Inrigting S.A.L.M., L.M.B. Swartkop/M.H.A.D.

Pho.ograph: Central Photographic Establishment S.A.A.F., A.F.B. Swartkop/M.H.A.S.

Photo: Zentrale phototechnische Anlage S.A.A.F., A.F.B. Swartkop/M.H.A.D. 


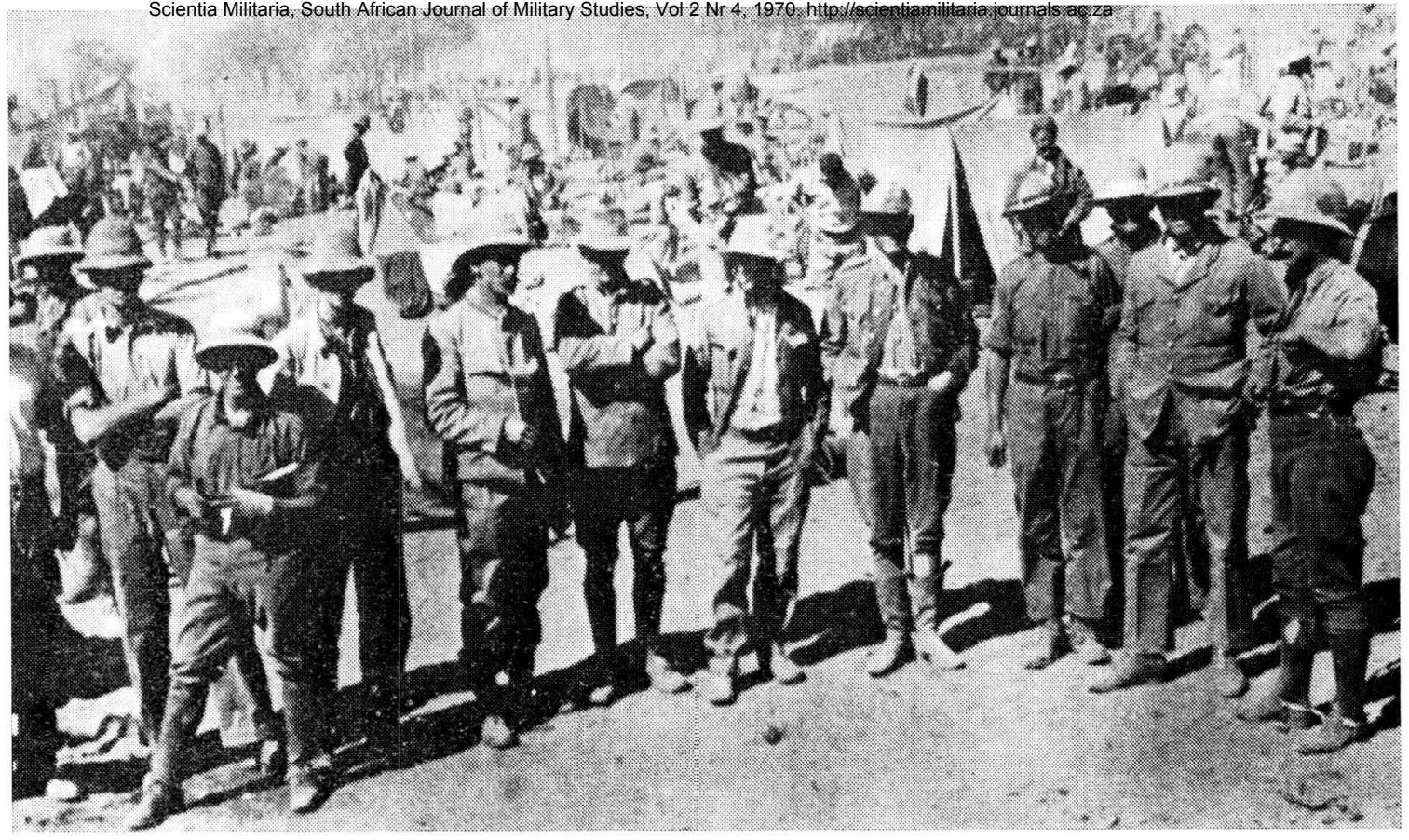

Suid-Afrikaanse krygsgevangenes tydens die veldtog in Suidwes (Tsumeb).

Foto: Aroiefbewaarplek van die Gebied, Windhoek.

Gereproduseer deur die Sentrale Fototegniese Inrigting S.A.L.M., L.M.B. Swartkop.

South African Prisoners of War during the South-West Africa campaign (Tsumeb).

Photograph: Archives Depot of the Territory, Windhoek.

Reproduced by the Central Photographic Establishment S.A.A.F., A.F.B. Swartkop.

Südafrikanische Kriegsgefangenen während des Südwestfeldzuges, photographiert bei Tsumeb.

Photo: Archivanlage des Gebiets, Windhuk.

Reproduziert von der Zentralen phototechnischen Anlage, S.A.A.F., A.F.B. Swartkop.

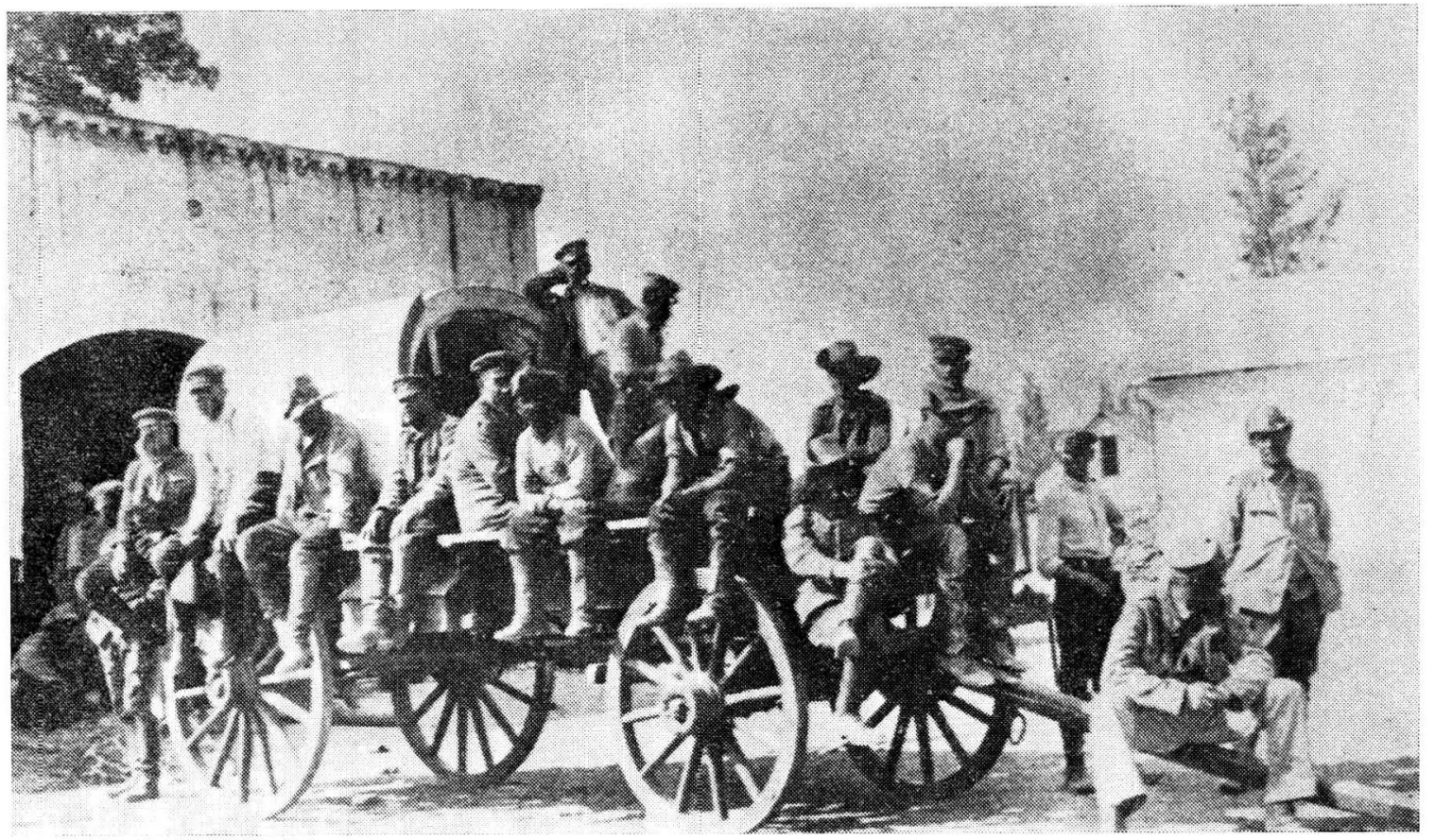

Duitse krygsgevangenes, Ghaub

Foto: Argiefbewaarplek van die Gebied. Windhoek.

Gereproduseer deur die Sentrale Fototegniese Inrigting S.A.L.M., L.M.B. Swartkop.

German Prisoners of War, Ghaub.

Photograph: Archives Depot of the Territory, Windhoek.

Reproduced by the Central Photographic Establishment S.A.A.F., A.F.B. Swartkop.

Deu'sche Kriegsgefangenen, Ghaub.

Photo: Archivanlage des Gebiets, Windhuk.

Reproduziert von der Zentralen phototechnischen Anlage, S.A.A.F., A.F.B. Swartkop. 


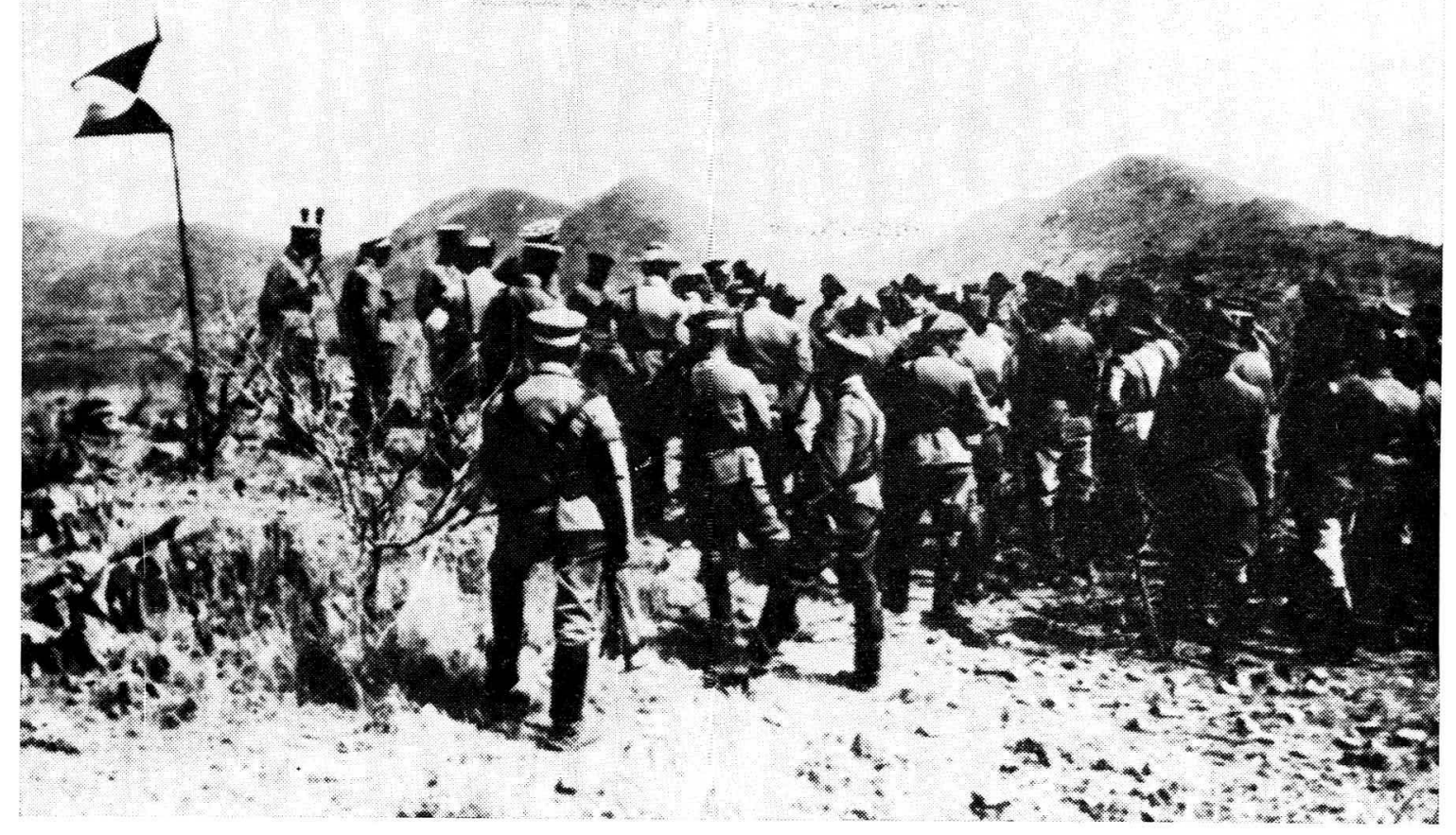

Suidwes-Afrika: Duitse troepe tydens 'n skietoefening.

Foto: Argiefbewaarplek van die Gebied, Windhoek.

Gereproduseer deur die Sentrale Fototegniese Inrigting S.A.L.M., L.M.B. Swartkop.

South-West Africa: German troops during range practice.

Photograph: Archives Depot of the Territory, Windhoek.

Reproduced by the Central Photographic Establishment S.A.A.F., A.F.B. Swartkop.

Südwest-Afrika: Deutsche Truppen während Schiessen.

Photo: Archivanlage des Gebiets, Windhuk.

Reproduziert von der Zentralen phototechnischen Anlage, S.A.A.F., A.F.B. Swartkop.

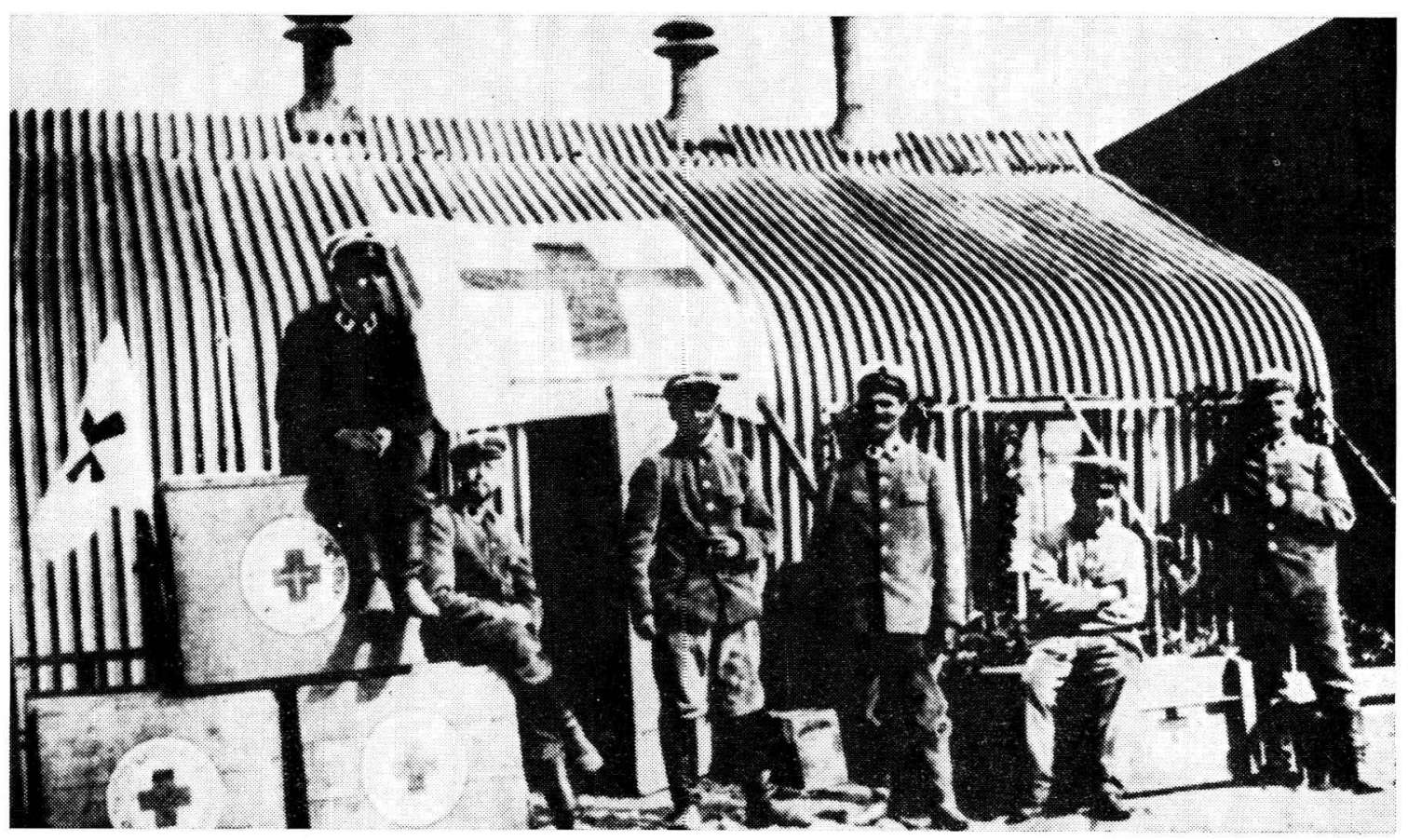

Rooi Kruis-depot, Windhoek, Duits Suidwes-Afrika.

Foto: Argiefbewaarplek van die Gebied, Windhoek.

Gereproduseer deur die Sentrale Fototegniese Inrigting S.A.L.M., L.M.B. Swartkop.

Red Cross Depot, Windhoek, German South-West Africa.

Photograph: Archives Depot of the Terriiory, Windhoek.

Reproduced by the Central Photographic Establishment S.A.A.F., A.F.B. Swartkop.

Depot vom „Roten Kreuz,” Windhuk, Deutsch Südwest-Afrika.

Photo: Archivanlage des Gebiets, Windhuk.

Reproduziert von der Zentralen phototechnischen Anlage, S.A.A.F., A.F.B. Swartkop. 


\section{ABRIDGED BIBLIOGRAPHY}

Backeberg, H. E. W.: DIE BETREKKINGE TUSSEN DIE SUID-AFRIKAANSE REBLIEK EN DUITSLAND TOT NA DIE JAMESON-INVAL (1852-1896). Archives Year Book for South African History, 1949.

Bauch, F. and Martens, A.: DUITSE KULTUUR AAN DIE KAAP/DEUTSCHE KULTUUR AM KAP/GERMAN CULTURE AT THE CAPE. Cape Town, 1964.

Breytenbach, J. H. (Ed.): GEDENKALBUM VAN DIE TWEEDE VRYHEIDSOORLOG. Kaapstad, 1949.

C. H. H.: WILHELM KARL FERDINAND BARON VON LINSINGEN. In Illustrierter Süd-Afrikanischer Volkskalender 1913. Johannesburg.

C. J. M.: OBERSTLEUTNANT FRIEDR SCHERMBRUCKER. In Illustrierter Süd-Afrikanischer Volkskalender 1913. Johannesburg.

DIE DUITSE BYDRAE TOT DIE ONTWIKKELING VAN SUID-AFRIKA. In Lantern, 11(4). Pretoria, 1962.

DAS GEFECHT BEÍ KAKAMAS/DIE GEVEG VAN KAKAMAS/THE BATTLE OF KAKAMAS, 4/2/1915. Cape Town, n.d.

Esterhuyse, J. A.: SOUTH WEST AFRICA 1880-1894. Cape Town, 1968.

Haupt, D. J.: DIE STAATSARTILLERIE VAN DIE SUID-AFRIKAANSE REPUBLIEK. M.A.-thesis. Pretoria, 1946.

Hintrager, O.: SÜDWESTAFRIKA IN DER DEUTSCHEN ZEIT. München, 1956.

Hoeflich, K. F.: DIE FRÜHZEIT SÜDWEST-AFRIKAS (1883-1915). In South West Africa Annual/Suidwes-Afrika-Jaarbock 1960. Windhoek, 1960.

Høge, J.: DIE GESKIEDENIS VAN DIE LUTHERSE KERK AAN DIE KAAP. Archives Year Book for South African History, 1946.

Hoge, J.: PERSONALIA OF THE GERMANS AT THE CAPE, 1652-1806. Archives Year Book for South African History, 1946.

Lemmer, C. J. C.: INLEIDING TOT DIE GESKIEDENIS VAN SUIDWES-AFRIKA. Kaapstad, 1941.

Ploeger, J. and Botha, H. J .: THE FORTIFICATION OF PRETORIA. FORT KLAPPERKOP - YESTERDAY AND TODAY. Pretoria, 1968.

Prinz, Johannes: DAS WÜRTTEMBERGISCHE KAPREGIMENT 1786-1808. Stuttgart, 1932.

Ras, Anna C.: DIE KASTEEL EN ANDER VROEË KAAPSE VESTINGWERKE 16521713. Kaapstad, 1959.

Rompel, F.: HEROES OF THE BOER WAR. London - The Hague, 1903.

Scheibert, J.: DER FREIHEITSKAMPF DER BUREN, Berlin, 1900.

Schiel, A.: 23 JAHRE STURM UND SONNENSCHEIN IN SÜDAFRIKA. Leipzig, 1902.

Schnell, E. L. G.: FOR MEN MUST WORK. THE STORY OF GERMAN IMMIGRATION TO THE CAPE. Cape Town, 1954.

Swemmer, T. P. E.: DIE GESKIEDENIS VAN DIE VRYSTAATSE ARTILLERIE. M.A.thesis. Bloemfontein, 1953.

THE GERMANS IN SOUTH WEST AFRICA. In The Cambridge History of the British Empire, (VIII). Cambridge, 1963.

THE UNION OF SOUTH AFRICA AND THE GREAT WAR 1914-1918. OFFICIAL HISTORY. Pretoria, 1924.

Van Niekerk, M. ADOLF SCHIEL EN DIE DUITSE KOMMANDO. M.A.-thesis. Pretoria, 1949.

Vedder, H.: DAS ALTE SÜDWESTAFRIKA. Berlin, 1934. BIS ZUM AUSBRUCH DES KRIEGES MIT WITBOOI. Berlin, 1899 